\title{
A COMPARATIVE STUDY ON WOUND HEALING USING PLACENTREX, COLLAGEN, VITAMIN C AND INSULIN
}

\author{
Ashok Tarachand Kamble1, Mayuri Khobragade Kamble², Pratik Abhishek ${ }^{3}$ \\ 1 Professor, Department of Surgery, Jawahar Lal Nehru Medical College and Acharya Vinoba Bhave Rural Hospital, Sawangi. \\ ${ }^{2}$ Associate Professor, Department of Surgery, Jawahar Lal Nehru Medical College and Acharya Vinoba Bhave Rural Hospital, Sawangi. \\ ${ }^{3}$ Resident, Department of Surgery, Jawahar Lal Nehru Medical College and Acharya Vinoba Bhave Rural Hospital, Sawangi.
}

\section{ABSTRACT}

\section{BACKGROUND}

The present study was undertaken in Department of Surgery, Jawahar Lal Nehru Medical College and Acharya Vinoba Bhave Rural Hospital, Sawangi (Meghe), Wardha. This study consists of 200 patients of various types of wounds. Equal number of patients of various type of wounds were randomly selected for the local treatment with Placentrex, collagen, vitamin C and insulin. Cleaning and debridement was done to all patients with infected wounds and systemic antibiotic was given according to sensitivity. Results were compared in terms of age, sex incidence, growth of culture organism, formation of healthy granulation tissue, percentage of reduction in size of wound, wound healing and duration of treatment in days/weeks.

\section{MATERIALS AND METHODS}

A total of 200 cases of different types of wounds were studied. Patients were divided into four groups containing 50 patients each. A comparative study was done between all the four groups with topical application of Placentrex, Collagen, Vitamin C and Insulin.

\section{RESULTS}

It was observed that Mean percentage reduction for Placentrex group was $88.22 \pm 8.90$, for Collagen group it was $83.60 \pm 12.57$, Insulin group was $37.40 \pm 16.26$ and for Vitamin $C$ it was $31.80 \pm 18.26$. By using one-way ANOVA significant variation is found in all four treatment groups $(\mathrm{F}=212.18$, $\mathrm{p}$-value $=0.000)$. After comparing all four groups by using TUKEY multiple comparison test significant difference is found between Insulin-Collagen, Insulin-Placentrex, Collagen-Vitamin C and Placentrex-Vitamin C. Mean percentage reduction is more in Placentrex group, hence we can conclude that Placentrex is the best modality of treatment for wound healing.

\section{CONCLUSION}

As per this present study in comparison Placentrex is superior in wound healing, collagen is the next best local applicant, vitamin C has some wound healing effects and lastly insulin has negligible results in wound healing.

\section{KEYWORDS}

PLACENTREX, Collagen, Vitamin C, Insulin.

HOW TO CITE THIS ARTICLE: Kamble AT, Kamble MK, Abhishek P. A comparative study on wound healing using Placentrex, collagen, vitamin C and insulin. J. Evolution Med. Dent. Sci. 2017;6(29):2366-2371, DOI: 10.14260/Jemds/2017/510

\begin{abstract}
BACKGROUND
The earliest accounts to wound healing dates back to 2000 B.C. when Sumerians first described two methods of wound healing: spiritual and physical, later Joseph Lister made significant contribution by introduction of antiseptics. In some lower animals such as stone crab can regenerate organs with the exception of bone and liver. ${ }^{1}$ The body's response to injury leads to release of various chemicals, so called mediators of healing which helps in wound healing. The lost tissue is not regenerated but is replaced by fibrous tissue, the similar events takes place in all the healing process irrespective of the inciting injury. Knowledge of wound healing and various promoters of wound healing allow the
\end{abstract}

Financial or Other, Competing Interest: None.

Submission 05-03-2017, Peer Review 27-03-2017,

Acceptance 04-04-2017, Published 10-04-2017.

Corresponding Author:

Pratik Abhishek,

Department of Surgery,

JNMC, Acharya Vinoba Bhave Rural Hospital,

Sawangi (Meghe) Wardha.

E-mail: pratikabhi1301@gmail.com

DOI: $10.14260 /$ jemds $/ 2017 / 510$

\section{(c) $($ ) $९$}

physician to manipulate the wound to achieve an optimal result in a rapid period of time.2,3,4

Wound healing is also dependent on any associated diseases to a major extent and has always been the primary objective of medical care. Many treatments have been used to heal wounds over the years for faster healing and reduced risk of infection. Continuous research has been done and is still undergoing to make safer and efficacious promoters of wound healing. ${ }^{5}$ This study was undertaken with a view to promote healthy granulation tissue, faster and safer wound healing with local application of-

- Placentrex.

- Collagen.

- Vitamin C.

- Insulin.

\section{MATERIALS AND METHODS}

The present study was conducted in patients of different kinds of wounds admitted in the surgery ward and also on outpatient basis at AVBR Hospital, Sawangi (Meghe), Wardha after the approval from Ethical Committee of the above Institute. A total of 200 cases of different types of wounds were studied. 
Patients were divided into four groups containing 50 patients each. A comparative study was done between all the four groups with topical application of-

$\begin{array}{ll}\text { - } & \text { Placentrex, } \\ \text { - } & \text { Vitamin } \mathrm{C}, \\ \text { - } & \text { Insulin. }\end{array}$

\section{Patient Selection}

All 200 patients were having different types of wounds and on various sites. Care was taken to reduce the various factors which delays wound healing such as diabetic state, haemoglobin levels and peripheral vascular disease. ${ }^{6}$

\section{Patient Preparation}

Local hygiene was maintained by cleaning the wound. Systemic antibiotics were administered to all the patients as per culture and sensitivity. All infected wounds were debrided before the local application of these agents. Daily dressing was done and size of the wound including the antero-posterior diameter, transverse diameter and the depth were studied at 7 days, 15 days and 25 days respectively. ${ }^{7}$ Adequate care was taken to keep the factors that delay wound healing to minimal like keeping the sugar levels under control in case of diabetic patients and giving pharmacotherapy in patients of peripheral vascular disease like trental and also improving the haemoglobin levels in case of anaemic patients.8,9

\section{Various Topical Agents used in the Study are as follows- Placentrex \\ Placentrex is the extract of human placenta. It is available in three forms- 1. Injections, 2. Lotion, 3. Gel form local application of Placentrex gel is used in this study.}

\section{Composition}

Each gram of Placentrex gel contains extract of human placenta and total nitrogen not more than $0.25 \% \mathrm{w} / \mathrm{w}$. Placentrex gel is natural vitamins, peptides, nucleotides and amino acid gel.

\section{Pharmacological Properties and Mechanisms of Action of Placental Extract (PLACENTREX) \\ Wound Healing}

Placentrex enhances wound healing significantly; increases collagen synthesis and improves tensile strength of healing tissue. Placentrex brings about maximum increases in the percent of DNA, total protein and epithelialisation.

\section{Anti-Inflammatory \\ Anti-inflammatory effect involving chemical mediators of the immunological response and analgesic effect have been reported. A CRF-like activity present in extract inhibits phospholipase A2 activity inhibiting formation of arachidonic acid, prostaglandins and leucotrienes.}

\section{Collagen}

It is major fibrous protein of extracellular connective tissues, and it is also the most ubiquitous and plentiful protein in the animal kingdom. Some $25 \%-35 \%$ of body protein is collagen. There are 13 types of collagen identified and they are characterised by specific amino acid sequences. The most abundant and well characterised collagen are Type 1 and Type 3.

\section{Availability of Collagen}

Local Application of Collagen for wound healing is available in this study. Collagen is available in sheet form produced from Bovine sources. It is composed mostly of Type 1 and Type 3 collagen.

\section{Salient Features}

1. Single application dressing in non-infected cases and clean wounds.

2. Quick and firm adherence.

3. Immediate pain relief.

\section{Mechanism of Action}

1. Collagen increases collagen synthesis capacity in granulation tissue of wound.

2. It activates angiogenesis, fibrogenesis, epithelialisation and histomacrophage function.

3. It increases chemoattraction, cell replication and collagen deposition stimulates cell growth, wound healing and tissue augmentation. 10

\section{Vitamin C [Ascorbic Acid]}

\section{Chemistry and Source}

Ascorbic acid is a 6-carbon organic acid with structural similarity to glucose. It is a potent reducing agent and is biologically active. Citrus fruits (lemon, orange), black currents are richest sources; others are tomatoes, potato, green chillies, cabbage and other vegetables. Human milk is richer in vitamin C (25-50 mg/L) than cow's milk.

\section{Physiological Role and Actions}

Vitamin C plays a role in many oxidative and other metabolic reactions, e.g. hydroxylation of proline and lysine residues of protocollagen- essential for formation and stabilisation of triple helix, formation of intercellular matrix and hydroxylation of carnitine conversion of folic acid to folinic acid.

\section{Therapeutic Uses}

1. Prevention of ascorbic acid deficiency in individuals at risk and scurvy,

2. Vitamin $\mathrm{C}$ enhances wound healing and can be used to accelerate healing of bed sores, chronic leg ulcer, nonhealing ulcer, burns, and postoperatively

3. Anaemia as it enhances the iron absorption. ${ }^{10}$

\section{Insulin}

Insulin is the hormone secreted by the beta cells of the Islets of Langerhans.

\section{Chemistry}

Insulin is a polypeptide with a molecular weight of about 6000 consisting of two amino acid chains A and B, linked by two disulphide bridge. The chains contain 21 and 30 amino acids respectively, all in a known sequence. The disulfide bridges are essential for its biological activity.

\section{Physiological and Pharmacological Actions}

1. It stimulates carrier mediated transport of glucose by recruiting glucose transporters (GLUT) from the cytoplasm to the cell membrane. 
2. Insulin binds to the specific insulin receptors in the cell membrane of the insulin sensitive and in sensitive cells and activates tyrosine kinase activity, which is inherent in the intracellular part of the insulin receptors. ${ }^{10}$

\section{RESULTS}

The present study consists of 200 patients of various types of wounds admitted for its management at Acharya Vinoba Bhave Rural Hospital, Sawangi (Meghe), Wardha during the period of April 2006 to September 2008. The observations of the study were as follows.

\begin{tabular}{|c|c|c|c|}
\hline $\begin{array}{c}\text { Sl. } \\
\text { No. }\end{array}$ & Type of Wound & $\begin{array}{c}\text { No. of } \\
\text { Patients }\end{array}$ & Percentage \\
\hline 1 & Traumatic Wound & 82 & $41 \%$ \\
\hline 2 & Diabetic Wound & 38 & $19 \%$ \\
\hline 3 & $\begin{array}{c}\text { Peripheral vascular disease } \\
\text { related wound }\end{array}$ & 12 & $6.0 \%$ \\
\hline 4 & Abscess & 12 & $6.0 \%$ \\
\hline 5 & Fournier's gangrene & 06 & $3.0 \%$ \\
\hline 6 & Bed sores & 14 & $7.0 \%$ \\
\hline 7 & Leprosy & 10 & $5.0 \%$ \\
\hline 8 & Wound gape & 20 & $10.0 \%$ \\
\hline 9 & Cellulitis & 06 & $3.0 \%$ \\
\hline Total & 200 & $\mathbf{1 0 0 \%}$ \\
\hline \multicolumn{3}{|c|}{ Table 1. Shows various Types of } \\
\hline \multicolumn{3}{|c|}{ Wounds and Number of Patients } \\
\hline
\end{tabular}

From Table No. 1 it is observed that various types of wounds like traumatic, diabetic, peripheral vascular disease, abscess and cellulitis, Fournier's gangrene, bed sore, leprosy, wound gape and other wounds were included in the study and number of patients were 82, 38,12,12, 06, 14, 10, 20 and 06 respectively. Among all these, traumatic wounds are found to be common.

\begin{tabular}{|c|c|c|}
\hline Age (Years) & Number of Patients & Percentage \\
\hline $0-10$ & 01 & $0.5 \%$ \\
\hline $11-20$ & 04 & $02 \%$ \\
\hline $21-30$ & 17 & $8.5 \%$ \\
\hline $31-40$ & 28 & $14 \%$ \\
\hline
\end{tabular}

\begin{tabular}{|c|c|c|}
\hline $41-50$ & 42 & $21 \%$ \\
\hline $51-60$ & 54 & $27 \%$ \\
\hline Above 60 & 54 & $27 \%$ \\
\hline Total & $\mathbf{2 0 0}$ & $\mathbf{1 0 0} \%$ \\
\hline \multicolumn{2}{|r|}{ Table 2. Age and Number of Patients }
\end{tabular}

In the present study, patients of any age were included and grouped at 10 years interval. About $75 \%$ patients were above 40 years.

\begin{tabular}{|c|c|c|c|}
\hline $\begin{array}{l}\text { Type of } \\
\text { Wound }\end{array}$ & $\begin{array}{l}\text { No. of Male } \\
\text { Patients }\end{array}$ & $\begin{array}{l}\text { No. of Female } \\
\text { Patients }\end{array}$ & Total \\
\hline Traumatic & 43 & 39 & 82 \\
\hline Diabetic & 24 & 14 & 38 \\
\hline $\begin{array}{c}\text { Peripheral vascular } \\
\text { disease }\end{array}$ & 11 & 1 & 12 \\
\hline Abscess & 8 & 4 & 12 \\
\hline Fournier's gangrene & 6 & - & 6 \\
\hline Bed sore & 9 & 5 & 14 \\
\hline Leprosy & 7 & 3 & 10 \\
\hline Wound gape & 13 & 7 & 20 \\
\hline Cellulites & 4 & 2 & 6 \\
\hline Total & 125 & 75 & 200 \\
\hline Percentage & $62.5 \%$ & $37.5 \%$ & $100 \%$ \\
\hline \multicolumn{4}{|c|}{$\begin{array}{l}\text { Table 3. Showing various Types of Wounds } \\
\text { and Number of Patients according to Sex }\end{array}$} \\
\hline
\end{tabular}

Table 3 shows that $125(62.5 \%)$ male patients and 75 (37.5\%) female patients were included in the study. Traumatic, abscess and cellulitis related wounds and wound gapes are found to be common in both sexes. Diabetic, peripheral vascular disease is found to be common in male patients. Among the wound related to peripheral vascular disease TAO (Thromboangiitis Obliterans) was a common one. One female patient was presented with peripheral vascular disease due to partial blockage in the right anterior and posterior tibial artery.

\begin{tabular}{|c|c|c|c|c|c|c|c|c|c|c|c|}
\hline \multirow[b]{2}{*}{ Organisms } & \multicolumn{9}{|c|}{ Number of Patients } & \multirow[b]{2}{*}{ Total } & \multirow[b]{2}{*}{$\%$} \\
\hline & Traumatic & Diabetic & $\begin{array}{c}\text { Peripheral } \\
\text { Vascular } \\
\text { Disease }\end{array}$ & Abscess & $\begin{array}{c}\text { Fournier's } \\
\text { Gangrene }\end{array}$ & $\begin{array}{l}\text { Bed } \\
\text { Sore }\end{array}$ & Leprosy & Wound & Cellulitis & & \\
\hline Staph a. & 24 & 11 & - & 4 & - & 2 & 4 & 4 & 1 & 50 & $25.0 \%$ \\
\hline Pseudomonas sp. & 09 & 2 & 1 & & & & 1 & & & 13 & $6.5 \%$ \\
\hline Klebsiella sp. & 7 & 5 & - & 1 & - & - & - & - & - & 13 & $6.5 \%$ \\
\hline E. coli & 5 & - & - & 1 & - & 4 & - & - & 1 & 11 & $5.5 \%$ \\
\hline E. coli + Staph aureus & 3 & - & - & - & 1 & & 2 & 2 & - & 8 & $4.0 \%$ \\
\hline Pseudomonas+Klebsiella sp. & 3 & - & - & 2 & - & - & - & 6 & - & 11 & $5.5 \%$ \\
\hline Pseudomonas+Staph. a & 6 & 12 & - & 1 & - & 1 & - & - & - & 20 & $10.0 \%$ \\
\hline Staph.a+Klebsiella.sp. & 3 & 3 & - & - & 1 & 2 & 1 & 3 & 1 & 14 & $7.0 \%$ \\
\hline Mixed & 8 & 4 & 6 & 1 & 2 & 1 & 1 & 2 & 1 & 24 & $12.0 \%$ \\
\hline Enterobacteria & & 1 & 2 & - & 1 & - & - & - & - & 4 & $2.0 \%$ \\
\hline Sterile & 14 & - & 3 & 2 & 1 & 4 & 1 & 5 & 2 & 32 & $16.0 \%$ \\
\hline Total & 82 & 38 & 12 & 12 & 6 & 14 & 10 & 20 & 6 & 200 & $100 \%$ \\
\hline
\end{tabular}

It has been observed from the above Table 4 that mixed infection was common in all various types of wound. Staphylococci and Klebsiella + Staphylococci were next common organisms cultured from various types of wounds. Other organisms isolated from the wounds were pseudomonas, Klebsiella, proteus and E. coli. 


\begin{tabular}{|c|c|c|c|c|}
\hline $\begin{array}{l}\text { Type of } \\
\text { Wound }\end{array}$ & Placentrex & Collagen & Vitamin C & Insulin \\
\hline Traumatic & 28 & 26 & 15 & 13 \\
\hline Diabetic & 8 & 7 & 13 & 10 \\
\hline $\begin{array}{c}\text { Peripheral } \\
\text { Vascular } \\
\text { Disease }\end{array}$ & 4 & 3 & 3 & 2 \\
\hline Abscess & 2 & 4 & 4 & 2 \\
\hline $\begin{array}{l}\text { Fournier's } \\
\text { gangrene- }\end{array}$ & 2 & 2 & 1 & 1 \\
\hline Bed sore & 2 & 2 & 6 & 4 \\
\hline Leprosy & 2 & 2 & 2 & 4 \\
\hline Wound gape & 2 & 2 & 4 & 12 \\
\hline Cellulitis & & 2 & 2 & 2 \\
\hline Total & 50 & 50 & 50 & 50 \\
\hline $\begin{array}{r}\text { Table } \\
\text { and Numb }\end{array}$ & $\begin{array}{l}\text { howing Me } \\
\text { of Patients }\end{array}$ & d of Lo & Applicati & unds \\
\hline
\end{tabular}

From the above Table 5, it has been observed that various types of wounds were randomly selected for local treatment with Placentrex, collagen, insulin and vitamin C. Majority of the patients has approximate wound size within 100 sq.cm. Few patients were having approximate wound size within $100-120$ sq.cm. All these patients were randomly selected for the local treatment with Placentrex, collagen, vitamin $\mathrm{C}$ and insulin.

\begin{tabular}{|c|c|c|c|c|}
\hline $\begin{array}{c}\text { Percentages } \\
\text { of Reduction } \\
\text { in Size of } \\
\text { Wounds }\end{array}$ & Placentrex & Collagen & Vitamin C & Insulin \\
\hline No response & - & - & $40 \%$ & $56 \%$ \\
\hline $10-20 \%$ & - & - & $24.0 \%$ & $22 \%$ \\
\hline $21-30 \%$ & - & - & $12 \%$ & $18 \%$ \\
\hline $31-40 \%$ & - & $4.0 \%$ & $12 \%$ & $4.0 \%$ \\
\hline $41-50 \%$ & - & $2.0 \%$ & $12 \%$ & - \\
\hline $51-60 \%$ & - & $2.0 \%$ & - & - \\
\hline $61-70 \%$ & $16 \%$ & - & - & - \\
\hline $71-80 \%$ & $14 \%$ & $32 \%$ & - & - \\
\hline $81-90 \%$ & $20 \%$ & $28 \%$ & - & - \\
\hline $91-100 \%$ & $50 \%$ & $32 \%$ & - & - \\
\hline \multicolumn{5}{|c|}{$\begin{array}{l}\text { Table 6. Showing Percentage of Reduction in Size of Wounds and } \\
\text { comparison of Percentage of Number of Patients treated with } \\
\text { Local Application of Placentrex, Collagen, Vitamin C and Insulin }\end{array}$} \\
\hline
\end{tabular}

From the above Table 6, it is observed that $50 \%$ and $32 \%$ of patients treated with Placentrex and collagen respectively showed $90 \%-100 \%$ of reduction in size of wound, whereas $56 \%$ and $40 \%$ of patients showed no response with the treatment of insulin and vitamin $\mathrm{C}$ respectively. Other $50 \%$ of patients showed $60 \%-90 \%$ reduction in size of wound treated with Placentrex, whereas $60 \%$ and $8 \%$ of patients showed $70 \%-90 \%$ and $30 \%-60 \%$ of reduction in size of wound respectively in collagen treated group; $60 \%$ of patients treated with vitamin C showed 10\% - 50\% reduction in size of wound and $44 \%$ of patients treated with insulin showed $10 \%-40 \%$ of reduction in size of wounds.

\begin{tabular}{|c|c|c|c|c|}
\hline $\begin{array}{c}\text { Total } \\
\text { Duration } \\
\text { of Complete } \\
\text { Treatment } \\
\text { (Weeks) }\end{array}$ & Placentrex & Collagen & Vitamin C & Insulin \\
\hline $0-1$ & 4 & & 4 & \\
\hline $1-2$ & 9 & 6 & & \\
\hline $2-3$ & 17 & 6 & & \\
\hline $3-4$ & 6 & 18 & 8 & \\
\hline $4-5$ & 8 & 10 & 12 & 8 \\
\hline $5-6$ & 6 & 6 & 10 & 22 \\
\hline $6-7$ & & & 9 & 6 \\
\hline Above 7 & - & 4 & 7 & 14 \\
\hline Total & 50 & 50 & 50 & 50 \\
\hline \multicolumn{5}{|c|}{$\begin{array}{c}\text { Table 7. Showing Duration of Complete Treatment and } \\
\text { Number of Patients Treated with Local Application of } \\
\text { Placentrex, Collagen, Vitamin C and Insulin }\end{array}$} \\
\hline
\end{tabular}

In Placentrex treated group, majority of patients 36 (72\%) were treated completely within 1 month and $14(28 \%)$ of patients required 4 - 6 weeks to get complete result. In collagen treated group, $60 \%$ of patients were treated completely with 1 month, $32 \%$ of patients showed complete treatment within $4-6$ weeks and $8.0 \%$ of patients required more than 7 weeks.

In vitamin C treated group, 36 (72\%) patients required 3 7 weeks and $7(14 \%)$ patients required more than 7 weeks to show complete treatment. In insulin treated group 36 (72\%) patients were completely treated within $4-7$ weeks and 14 (28\%) patients required more than 7 weeks.

Comparison of Percentage Reduction in Size of Wounds with Local Application of PLACENTREX, Insulin, Collagen and Vitamin C

\section{A. Descriptive Statistics}

\begin{tabular}{|c|c|c|c|c|c|c|c|c|}
\hline & \multirow[t]{2}{*}{$\mathbf{N}$} & \multirow[t]{2}{*}{ Mean } & \multirow{2}{*}{$\begin{array}{c}\text { Std. } \\
\text { Deviation }\end{array}$} & \multirow[t]{2}{*}{ Std. Error } & \multicolumn{2}{|c|}{$\begin{array}{l}\text { 95\% Confidence } \\
\text { Interval for Mean }\end{array}$} & \multirow[t]{2}{*}{ Minimum } & \multirow[t]{2}{*}{ Maximum } \\
\hline & & & & & Lower Bound & Upper Bound & & \\
\hline Insulin & 50 & 37.40 & 16.26 & 2.30 & 32.77 & 42.02 & 0.00 & 60.00 \\
\hline Collagen & 50 & 83.60 & 12.57 & 1.77 & 80.02 & 87.17 & 60.00 & 100.00 \\
\hline Placentrex & 50 & 88.22 & 8.90 & 1.25 & 85.68 & 90.75 & 60.00 & 100.00 \\
\hline Vitamin C & 50 & 31.80 & 18.26 & 2.58 & 26.61 & 36.98 & 0.00 & 60.00 \\
\hline Total & 200 & 60.25 & 29.56 & 2.09 & 56.13 & 64.37 & 0.00 & 100.00 \\
\hline
\end{tabular}


B. One-Way ANOVA

\begin{tabular}{|c|c|c|c|c|c|}
\hline Source of Variation & Sum of Squares & Df & Mean Square & F & P-value \\
\hline Between Groups & 132953.41 & 3 & 44317.80 & 212.1 & 0.000 \\
Within Groups & 40936.58 & 196 & 208.86 & 8 & HS, p $<0.0001$ \\
\hline Total & $\mathbf{1 7 3 8 8 9 . 9 9}$ & $\mathbf{1 9 9}$ & & & \\
\hline
\end{tabular}

HS- Highly Significant, $\mathrm{p}<0.0001$

C. Multiple Comparisons: Tukey HSD

\begin{tabular}{|c|c|c|c|c|c|c|}
\hline \multirow{2}{*}{\multicolumn{2}{|c|}{ Group }} & \multirow{3}{*}{\begin{tabular}{|c|} 
Mean Difference (I - J) \\
-46.20
\end{tabular}} & \multirow{3}{*}{$\begin{array}{c}\text { Std. Error } \\
2.89\end{array}$} & \multirow{3}{*}{$\begin{array}{c}\text { P-value } \\
0.000 \\
\text { HS, } p<0.0001\end{array}$} & \multicolumn{2}{|c|}{ 95\% Confidence Interval } \\
\hline & & & & & \multirow{2}{*}{$\begin{array}{c}\text { Lower Bound } \\
-53.68\end{array}$} & \multirow{2}{*}{$\begin{array}{c}\text { Upper Bound } \\
-38.71\end{array}$} \\
\hline \multirow{3}{*}{ Insulin } & Collagen & & & & & \\
\hline & Placentrex & -50.82 & 2.89 & $\begin{array}{c}0.000 \\
\text { HS, } p<0.0001\end{array}$ & -58.30 & -43.33 \\
\hline & Vitamin C & 5.60 & 2.89 & $0.216, \mathrm{NS}, \mathrm{p}>0.05$ & -1.88 & 13.08 \\
\hline \multirow[b]{2}{*}{ Collagen } & Placentrex & -4.62 & 2.89 & $0.382, \mathrm{NS}, \mathrm{p}>0.05$ & -12.10 & 2.86 \\
\hline & Vitamin C & 51.80 & 2.89 & $\begin{array}{c}0.000 \\
\text { HS, } p<0.0001\end{array}$ & 44.31 & 59.28 \\
\hline Placentrex & Vitamin C & 56.42 & 2.89 & $\begin{array}{c}0.000 \\
H S, p<0.0001\end{array}$ & 48.93 & 63.90 \\
\hline
\end{tabular}

From the above table, it was observed that mean percentage reduction for Placentrex group was $88.22 \pm 8.90$, for Collagen group it was $83.60 \pm 12.57$, Insulin group it was $37.40 \pm 16.26$ and for Vitamin $C$ it was $31.80 \pm 18.26$. By using One-Way ANOVA significant variation is found in all four treatment groups $(F=212.18$, $p$-value $=0.000)$.

\section{DISCUSSION}

In Placentrex treated group, $80 \%$ of patient's wound treated with Placentrex healed completely and does not require any secondary operative procedure. In $20 \%$ of patients, due to larger size wound skin grafting was required.11

In collagen treated group, $50 \%$ of patients' wound healed completely and $28 \%$ of patients required skin grafting and $22 \%$ of patients required resuturing.

In vitamin $\mathrm{C}$ and insulin treated group majority of patients showed no response or minimal reduction in size of wound, so all patients were treated with vitamin $\mathrm{C}$ and insulin were required for skin grafting or resuturing according to wound size.

In Placentrex treated group, majority of patients were completely treated within one month and only few patients required 4 - 6 weeks to show complete treatment. In collagen treated group, majority of patients showed complete response within one and a half month and only one patient required more than 7 weeks to show complete response.

Duration of complete treatment was increased in insulin and vitamin $\mathrm{C}$ treated group as compared to Placentrex and collagen treated patients.

\section{In Patients treated with Placentrex following Advantages} were noted-

1. It promotes early healthy granulation tissue, epithelialisation and healing.

2. It combats infections and reduces the incidence of infection.

3. Relief from pain.

4. It is nontoxic and non-antigenic.

5. It is economical.

6. It has simple method of application.
Collagen is the next best local applicant; it also promotes healthy granulation tissue; $50 \%$ of patients showed complete wound healing and reduces hospital stay. ${ }^{12,13}$

Next to collagen vitamin $\mathrm{C}$ has some wound healing effect, as majority of patients showed $10 \%-50 \%$ reduction in size of wound one month after the treatment with vitamin C. Insulin has minimal wound healing effects as $50 \%$ of patients showed no response and other $50 \%$ of patients showed very minimal reduction in size of wound. In both vitamin $C$ and insulin treated group, patients required longer healing duration. ${ }^{12}$

Mean percentage reduction for Placentrex group was $88.22 \pm 8.90$, for Collagen group it was $83.60 \pm 12.57$, Insulin group was $37.40 \pm 16.26$ and for Vitamin $C$ it was $31.80 \pm 18.26$. By using one-way ANOVA significant variation is found in all four treatment groups $(\mathrm{F}=212.18$, $\mathrm{p}$-value $=0.000$ ).

After comparing all four groups by using TUKEY, multiple comparison test significant difference is found between Insulin-Collagen, Insulin-Placentrex, Collagen-Vitamin $C$ and Placentrex-Vitamin C. Mean percentage reduction is more in Placentrex group, hence we can conclude that Placentrex is the best modality of treatment for wound healing.

As per this present study in comparison, Placentrex is superior in wound healing, collagen is the next best local applicant, vitamin $\mathrm{C}$ has some wound healing effects and lastly insulin has negligible results in wound healing.

\section{CONCLUSION}

After comparing all four groups by using TUKEY multiple comparison Test, significant difference is found between Insulin-Collagen, Insulin-Placentrex, Collagen-Vitamin $\mathrm{C}$ and Placentrex-Vitamin C. Mean percentage reduction is more in 


\section{Jemds.com}

Placentrex group; hence, we can conclude that Placentrex is the best modality of treatment for wound healing.

As per this present study in comparison, Placentrex is superior in wound healing; collagen is the next best local applicant; vitamin $\mathrm{C}$ has some wound healing effects and lastly insulin has negligible results in wound healing.

\section{REFERENCES}

[1] Carel A. Treatment of wounds. Journal of American Medical Association 1916;(55):2148-52.

[2] Filatov VP. Tissue therapy. My path in science. Moscow: Foreign Language Publishing House 1933:3883.

[3] King H. The Oldest Code of Laws in the World. Lawbook Exchange Ltd 2000. ISBN 9781584770619.

[4] Lock S, Dunea G, Last JM. The oxford illustrated companion to medicine. $3^{\text {rd }}$ edn. USA: Oxford University Press 2001. ISBN 0192629506.

[5] Pilcher JE. Guy de Chauliac and Henri de Mondeville,- A Surgical Retrospect. Ann Surg 1895;21(1):84-102.

\section{Original Research Article}

[6] Paré A. The catholic encyclopedia. Vol. 11. New York: Robert Appleton Company 1911.

[7] Thiersh C. Archiv für pathologische Anatomie und Physiologie, und für klinische Medizin. Berlin 1896;143:679.

[8] Ackerknechi EH. Primotive surgery. Amercian Anthropologist 1947;49:25-45.

[9] Troensegaard-Hansen E. Amniotic grafts in chronic skin ulceration. Lancet 1950;1(6610):859-60.

[10] Trelford JD, Hanson FW, Anderson DG, et al. Wound healing and the amniotic membrane. J Med J Med 1975;6(5-6):383-8.

[11] Bapat CV, Kothary PM. Preliminary report on acceleration of wound healing by amnion membrane graft. Indian J Med Res 1974;62(9):1342-6.

[12] Taylor TV, Rimmer S, Day B, et al. Ascorbic acid supplementation in the treatment of pressure-sores. Lancet 1974;2(7880):544-6.

[13] Afifi AM, Ellis L, Huntsman RG, et al. High dose ascorbic acid in the management of thalassaemic leg ulcers- a pilot study. Br J Dermatol 1975;92(3):339-41. 